\title{
Relative Roles of Follicle-stimulating Hormone and Luteinizing Hormone in the Control of Inhibin Secretion in Normal Men
}

\author{
Robert I. McLachlan, Alvin M. Matsumoto, Henry G. Burger, “ David M. de Kretser, ${ }^{\star}$ and William J. Bremner \\ Endocrinology Section, Gerontology Research, Education and Clinical Center, Veterans Administration Medical Center, Seattle, \\ Washington, 98108; Population Center for Research in Reproduction, Division of Endocrinology, Department of Medicine, \\ University of Washington School of Medicine, Seattle, Washington 98195; and *Medical Research Center, Prince Henry's \\ Hospital and ${ }^{\ddagger}$ Department of Anatomy, Monash University, Melbourne, Australia 3168
}

\begin{abstract}
The glycoprotein hormone inhibin is produced by the Sertoli cells of the testis under the influence of follicle-stimulating hormone (FSH) and is postulated in turn to inhibit FSH secretion. Luteinizing hormone (LH) is not recognized to have an important role in the control of inhibin secretion in any species. To determine the relative roles of $\mathrm{FSH}$ and $\mathrm{LH}$ in the control of inhibin secretion in man, we examined the effects of selective FSH and LH replacement on serum inhibin levels in normal men whose endogenous gonadotropins were suppressed by testosterone (T). After a 3-mo control period, nine men received $200 \mathrm{mg}$ T enanthate i.m. weekly for 3-9 mo. During T treatment, serum LH and FSH levels were markedly suppressed and serum inhibin levels fell to $40 \%$ of control values. While continuing T, 3-5 mo of treatment with purified hFSH $(n=4)$ or hLH $(n=4)$ increased the respective serum gonadotropin level into the upper normal range and significantly increased inhibin levels back to 64 and $55 \%$ of control values, respectively. Supraphysiological LH replacement with high doses of human chorionic gonadotropin $(n=3)$ returned serum inhibin levels to $63 \%$ of control values. In no case did inhibin levels return fully to control levels. In conclusion, serum inhibin levels fell during gonadotropin suppression and were partially and approximately equally restored by either FSH or LH treatment. FSH presumably acts directly on the Sertoli cell to increase inhibin secretion whereas LH may act via increases in intratesticular $\mathbf{T}$ levels and/or other factor(s).
\end{abstract}

\section{Introduction}

Inhibin is a glycoprotein produced by the testis and ovary and has been postulated to have an important role in the regulation of pituitary follicle-stimulating hormone (FSH) secretion (1). In the male, in vitro studies have shown that Sertoli cells (2-5) secrete inhibin under the influence of FSH but not luteinizing hormone (LH) (5-9). The effect of LH on testicular inhibin secretion in vivo is unknown. Inhibin (a glycoprotein heterodimer) was recently purified from ovarian follicular fluid

This paper was published in abstract form in 1988 Clin. Res. 36:125a. (Abstr.)

Address reprint requests to Dr. Robert I. McLachlan, Veterans Administration Medical Center (111), 1660 South Columbian Way, Seattle, WA 98108.

Received for publication 18 November 1987 and in revised form 9 March 1988.

J. Clin. Invest.

(c) The American Society for Clinical Investigation, Inc.

0021-9738/88/09/0880/05 $\$ 2.00$

Volume 82, September 1988, 880-884
(10-12), cloned, and sequenced (13-15). Pure bovine inhibin has been used in the development of sensitive and specific RIA systems applicable to human serum $(16,17)$, allowing investigation of inhibin levels in women during ovulation induction $(18,19)$, the normal menstrual cycle (17), and pregnancy $(19,20)$.

In previous studies, we have demonstrated that both FSH and $\mathrm{LH}$ are required to maintain quantitatively normal spermatogenesis in man (21-25). As a result of the suppression of gonadotropins, testosterone $(\mathrm{T})^{1}$ administration to normal men markedly reduced sperm counts. While continuing $T$, selective replacement with physiological doses of either highly purified human FSH (22) or LH (23), or supraphysiological doses of human ohorionic gonadotropin (hCG) $(21,24)$, were each associated with only partial restoration of spermatogenesis, indicating a separate role for each gonadotropin. Quantitatively normal spermatogenesis could only be restored with replacement of both gonadotropins (25).

As Sertoli cell function is intimately related to both spermatogenesis and inhibin production, this study aimed to examine the effect on inhibin levels of $\mathrm{T}$-induced gonadotropin suppression in normal men and subsequent selective replacement with FSH or LH. Specifically, we sought to determine whether inhibin secretion decreased during gonadotropin suppression, and, if so, whether inhibin levels could be stimulated by selective replacement of FSH or LH in physiological amounts.

\section{Methods}

\section{Subjects}

A total of nine normal men ( $25-40 \mathrm{yr}$ old) volunteered to participate in these studies. The experimental protocols, sperm counts, and gonadotropin levels have been described previously (22-24). The normality of subjects was established by $(a)$ complete medical histories and physical examinations; $(b)$ routine hematological analysis, blood chemistry, coagulation times, and urinalysis; $(c)$ six semipal fluid analyses obtained over a 3-mo period (sperm concentration $>20$ million/ml, sperm motility $>50 \%$ and $>60 \%$ oval forms); and (d) normal basal LH, FSH, and testosterone levels; normal LH and FSH secretory patterns on blood sampling every 20 min over $6 \mathrm{~h}$ and normal FSH and LH responses to a 4-h continuous intravenous infusion of $50 \mu \mathrm{g}$ of gonadotropin-releasing hormone (GnRH).

\section{Experimental protocol}

All subjects underwent a 3-mo control period during which no hormones were given and only blood samples were collected and semen

1. Abbreviations used in this paper: $\mathrm{bFF}$, bovine follicular fluid; CV, coefficient of variation; GnRH, gonadotropin-releasing hormone; hCG, human chorionic gonadotropin; T, testosterone. 
analyses performed. After the control period, all subjects received 200 mg testosterone enanthate (Delatestryl; E. R. Squibb and Sons, Princeton, NJ) i.m. weekly until sperm counts were $<2$ million $/ \mathrm{ml}$, which occurred after 2-4 mo of treatment. The duration of T alone treatment was between 3 and 5 mo (studies 1 and 2) or 9 mo (study 3). While continuing $T$ administration, selective gonadotropin replacement regimens were undertaken as follows.

Study 1. In four subjects, $100 \mathrm{IU}$ hFSH s.c. daily was administered together with T for $3 \mathrm{mo}$. The hFSH preparation (LER 1577, Lot No. 4) was kindly provided by the National Pituitary Agency, Baltimore, MD. As previously described, this preparation contained $<1 \%$ contamination with LH bioactivity. After the FSH plus T period, FSH injections were stopped and $\mathrm{T}$ continued until three successive sperm counts were again $<5$ million/ml; this occurred between 1-5 mo of $\mathrm{T}$ therapy. After $T$ treatment, the subjects entered a recovery period until three successive sperm counts were within the subject's own control range.

Study 2. In four subjects, $1,100 \mathrm{IU}$ hLH s.c. daily was coadministered with $\mathrm{T}$ for a period of 4-6 mo. The hLH preparation (LER 1549, batch A-3) was also provided by the National Pituitary Agency, Baltimore, MD. This preparation contained $<0.2 \%$ contamination with FSH bioactivity as assessed in a rat ovarian augmentation bioassay. All hormones were then stopped and the subjects entered a recovery period until three successive sperm counts returned into the subject's own control range.

Study 3. In three men, 5,000 IU hCG (Profasi; Serono Laboratories, Inc., Braintree, MA) i.m. three times weekly was coadministered with $\mathrm{T}$ for a period of 6-7 mo. Both hormones were then ceased and the subjects entered a recovery period until three successive sperm counts were within the subjects' control range.

Measurements. Throughout the study periods, blood samples were obtained each month and semen analyses performed twice monthly. A 6-h urine sample was obtained from each subject at the end of the control, T alone, and T plus gonadotropin periods. Blood samples were obtained immediately before hormone injections and serum was stored at $-20^{\circ} \mathrm{C}$ before assay. For the assay of serum inhibin, the current study made use of residual serum samples from the original three studies (22-24).

Radioimmunoassays. A heterologous RIA for human serum inhibin was used based on a previously described method (17). The assay was modified to use a new inhibin antiserum (As 1989), raised in a New Zealand white rabbit to $31 \mathrm{kD}$ bovine follicular fluid (bFF) inhibin. The RIA using this antiserum showed no interference from castrate serum and an enhanced sensitivity when compared with the previous method. This RIA was specific to intact inhibin, showing $<1 \%$ cross-reactivity with transforming growth factor $\beta$, bovine activin $A$, and free inhibin subunits obtained after reduction and alkylation of $31 \mathrm{kD}$ bovine inhibin. A partially purified human follicular fluid inhibin preparation was prepared for use as the RIA standard as described (17). This material was calibrated in terms of its in vitro inhibin bioactivity using a bFF inhibin standard preparation itself previously calibrated against an ovine testicular lymph preparation of defined unitage $1 \mathrm{U} / \mathrm{mg}$ (26). Male serum samples showed parallel dose-response lines to the RIA standard and a serum pool obtained from women undergoing ovulation induction, which was used as quality control. In the RIA, 200- $\mu$ l samples were assayed in duplicate. The sensitivity of the assay was $100 \mathrm{U} /$ /iter. The interassay coefficient of variation $(\mathrm{CV})$ was $11 \%$ and the intrassay $\mathrm{CV}$ in the upper, mid, and lower portions of the standard curve were $12.0,3.3$, and $4.8 \%$, respectively for five assays. Inhibin immunoactivity has been shown to be stable during repeated freezing and thawing (17). Inhibin levels in the study subject's control sera were $\sim 25 \%$ lower than those of a recently examined group of normal young men, suggesting the possibility of some loss of immunoactivity during the prolonged storage of the samples used in this study. However, all samples used for this study had been stored for approximately the same length of time, so that any loss of immunoactivity with storage could not account for the differences found between the various hormonal manipulations in these studies.
Serum FSH and LH were determined by RIA as described previously (21) using reagents distributed by the National Pituitary Agency and using the reference preparation LER 907. In the FSH RIA, the first antibody was rabbit anti-human FSH batch No. 5 and the tracer was HS-1 radiolabeled with ${ }^{125} \mathrm{I}$ using chloramine T. The sensitivity of the assay was $25 \mu \mathrm{g}$ /liter. The intraassay CV was $7.3 \%$ and the interassay CV was $9.7 \%$. Urinary FSH excretion was measured by RIA after acetone precipitation of urine (27) as described previously (21) using the Second International Reference Preparation of human menopausal gonadotropin as the reference standard. In the LH RIA, the tracer was purified hCG (supplied courtesy of Dr. C. Alvin Paulsen, Department of Medicine, University of Washington) that was radiolabeled with ${ }^{125}$ I by chloramine T. The sensitivity of the assay was 6 $\mu \mathrm{g} /$ liter and the intra- and interassay CVs were 5.5 and $8.4 \%$, respectively.

Bioassay. Serum LH levels were measured by in vitro bioassay using a modification (21) of the procedures described by Van Damme et al. (28) and Dufau et al. (29). T production was measured from dispersed Leydig cells isolated from immature Swiss Webster mice (age 5-7 wk). The reference standard was LER 907. All samples were run in duplicate and the detection limit of the assay was $100 \mu \mathrm{g} /$ liter. The mean intra- and interassay CVs for pooled human sera were 14 and $24 \%$, respectively.

Seminal fluid analysis. Sperm concentrations were determined using a Coulter counter (Coulter Electronics Inc., Hialeah, FL), whereas concentrations $<15 \mathrm{million} / \mathrm{ml}$ were confirmed by direct determination using a hemocytometer as described.

Statistical analysis. Monthly inhibin levels during each phase of treatment were averaged for each patient. To ensure that each hormonal manipulation had sufficient time to both be effective and to have been adequately washed out before the next study period, only results obtained during the following time periods were included in these analyses: $(a)$ control period, all values until the day of commencement of $\mathrm{T} ;(b) \mathrm{T}$ alone and $\mathrm{T}$ plus gonadotropin periods, all values obtained after $2 \mathrm{wk}$ of $\mathrm{T}$ or gonadotropin treatment until the day of commencement of the next study period; $(c)$ subsequent periods on $\mathrm{T}$ alone, all values obtained at least $2 \mathrm{wk}$ after cessation of gonadotropin therapy until the day of the next hormonal administration or within 2 wk of the last $\mathrm{T}$ injection in the early recovery phase; and $(d)$ recovery period, all values obtained at least 4 wk after the cessation of $\mathrm{T}$.

Mean monthly serum LH and FSH levels and mean sperm concentrations for each period of study were calculated for each patient as described. Sperm concentrations were not normally distributed and values were log-transformed before statistical analysis.

Mean hormonal values for each patient during the various treatment periods were obtained. Analysis of variance with repeated measures was used to detect a significant change across the treatments. The existence of a significant difference between treatments was determined by paired $t$ test with correction for multiple comparisons using the Bonferroni method. Values are expressed as mean \pm SEM.

\section{Results}

Study 1. The changes in serum inhibin levels in the four subjects receiving $100 \mathrm{IU}$ hFSH daily are shown in Fig. 1. Inhibin levels decreased to $35 \%$ of control values after $\mathrm{T}$ administration (432 \pm 34 vs. $152 \pm 14$ U/liter, $P<0.02$ ). During hFSH treatment, inhibin levels increased $(P<0.05)$ to between 60 and $76 \%$ control values with a mean level of $278 \pm 16 \mathrm{U} /$ liter. Nonetheless, inhibin levels were still significantly lower than control $(P<0.05)$. After cessation of hFSH, inhibin levels again fell to $150 \pm 10 \mathrm{U} /$ liter on $\mathrm{T}$ alone, then rose to $418 \pm 44$ $\mathrm{U} /$ liter after cessation of T (NS vs. control).

Serum-immunoreactive FSH levels were suppressed from control levels $(98 \pm 21 \mu \mathrm{g} /$ liter $)$ to undetectable $(<25 \mu \mathrm{g} /$ liter $)$ levels during $\mathrm{T}$ treatment. Urinary FSH excretion was sup- 


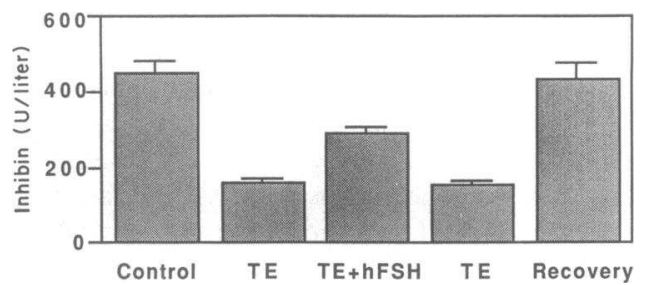

Figure 1. Serum inhibin levels during control, testosterone $(200 \mathrm{mg}$ TE i.m. weekly) alone, TE plus hFSH (100 IU s.c. daily), TE alone, and recovery periods in four normal men. Values represent mean $\pm S E$ inhibin levels.

pressed to levels comparable to those of prepubertal or hypogonadotropic subjects (21). After hFSH treatment, FSH levels then increased to just above the upper limit of the normal range (273 $\pm 44 \mu \mathrm{g} /$ liter). Urinary FSH excretion was similarly restored into the upper normal range. Serum LH bioactivity was markedly suppressed to the limit of assay detection throughout both $T$ and $T$ plus FSH treatment.

During $\mathrm{T}$ therapy, sperm counts declined markedly from a mean of 99 million/ml to $<2$ million/ml in all subjects. During $\mathrm{hFSH}$ treatment, sperm counts increased significantly to $33 \pm 7$ million $/ \mathrm{ml}$. In no case did sperm counts consistently reach the individual's control values. Upon withdrawal of $\mathrm{hFSH}$, counts again fell to $<1$ million on $\mathrm{T}$ alone. In two subjects, sperm counts were obtained after the recovery period and both were within the individual's own control range.

Study 2. The changes in serum inhibin in the four subjects receiving $\mathrm{hLH}$ treatment are shown in Fig. 2. During $\mathrm{T}$ treatment, inhibin levels decreased to $40 \%$ of control values ( $432 \pm 60$ vs. $172 \pm 40 \mathrm{U} /$ liter, $P<0.02$ ). hLH treatment led to a significant $(P<0.05)$ increase in inhibin levels to $55 \%$ of control levels $(240 \pm 60 \mathrm{U} / \mathrm{liter})$, which was still significantly $(P$ $<0.02)$ lower than control values. In the recovery phase, inhibin levels returned to control levels (418 $\pm 64 \mathrm{U} /$ liter).

Serum LH bioactivity fell markedly during $\mathrm{T}$ treatment ( $390 \pm 20$ vs. $120 \pm 10 \mu \mathrm{g} /$ liter, $P<0.001$ ). hLH injections restored LH bioactivity to the control range when samples were collected immediately before an LH injection $(400 \pm 40 \mu \mathrm{g} /$ liter) and a peak level, obtained $8 \mathrm{~h}$ after injection, at the upper limit of the normal male range ( $750 \pm 150 \mu \mathrm{g}$ /liter). Serum FSH was suppressed from control values $(98 \pm 12 \mu \mathrm{g} / \mathrm{liter})$ to undetectable levels $(<25 \mu \mathrm{g} /$ liter $)$ where it remained until the recovery period. Similarly, urinary FSH excretion was suppressed into the prepubertal range throughout $T \pm h L H$ treatment.

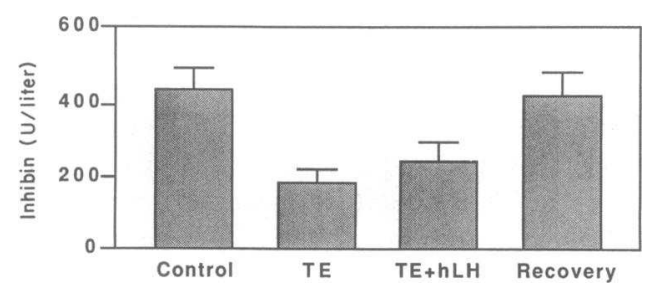

Figure 2. Serum inhibin levels during control, testosterone (200 $\mathrm{mg}$ TE i.m. weekly) alone, TE plus hLH (1,100 IU s.c. daily) and recovery periods in four normal men. Values represent mean $\pm S E$ inhibin levels.
Sperm concentrations were markedly suppressed by $\mathrm{T}$ $(98 \pm 17$ million $/ \mathrm{ml} \mathrm{to}<4 \mathrm{million} / \mathrm{ml})$ and partially restored by hLH treatment ( $19 \pm 4$ million/ml after 3 mo of treatment). In no case did the sperm count consistently reach the individual's control range. After recovery, sperm counts returned to control levels in both subjects in whom this was assessed.

Study 3. The changes in serum inhibin in the three subjects receiving hCG treatment are shown in Fig. 3. During T treatment, inhibin levels decreased to $38 \%$ of control values ( $492 \pm 170$ vs. $186 \pm 86 \mathrm{U} /$ liter). hCG treatment led to a significant $(P<0.05)$ increase in inhibin levels to $63 \%$ of control values $(308 \pm 90 \mathrm{U} / \mathrm{liter})$, which was still lower than control levels. In the recovery phase, inhibin levels returned to control levels (498 $\pm 90 \mathrm{U} /$ liter).

Serum LH immunoactivity fell during $\mathrm{T}$ treatment from $28 \pm 4$ to $7 \pm 1 \mu \mathrm{g} /$ liter (at the limit of assay sensitivity). hCG administration led to a marked elevation in serum LH-like immunoactivity ( $>200 \mu \mathrm{g} /$ liter) due to cross-reactivity of hCG in the LH RIA. Serum FSH was suppressed from control levels $(125 \pm 34 \mu \mathrm{g} /$ liter $)$ to undetectable $(<25 \mu \mathrm{g} /$ liter $)$ levels during both $\mathrm{T}$ alone and $\mathrm{hCG}+\mathrm{T}$ administration. Urinary FSH excretion was suppressed to prepubertal levels during both of these periods.

Sperm counts were markedly suppressed by $T(82 \pm 9$ million/ml to $<1 \mathrm{million} / \mathrm{ml}$ ) and substantially restored by $\mathrm{hCG}$ treatment ( $22 \pm 4 \mathrm{million} / \mathrm{ml}$ after $3 \mathrm{mo}$ of hCG). In some samples, sperm counts were within the subject's control range; however, the mean sperm count remained below control values.

\section{Discussion}

Our results show that serum inhibin levels in normal men decrease after the suppression of gonadotropin levels by testosterone administration and are partially restored by either FSH or LH replacement. During T therapy, levels of FSH immunoactivity and LH bioactivity were suppressed into the prepubertal range. Serum inhibin levels were suppressed to levels similar to those observed in early puberty and in subjects with Kallmann's syndrome before pulsatile GnRH treatment (unpublished observations). Similarly, a substantial fall in testicular inhibin content has been reported after hypophysectomy in rats (30). GnRH agonist administration to women also markedly reduced serum estradiol and inhibin levels as a consequence of functional gonadotropin withdrawal (31). These studies underline the trophic effect of gonadotropins on gonadal inhibin production.

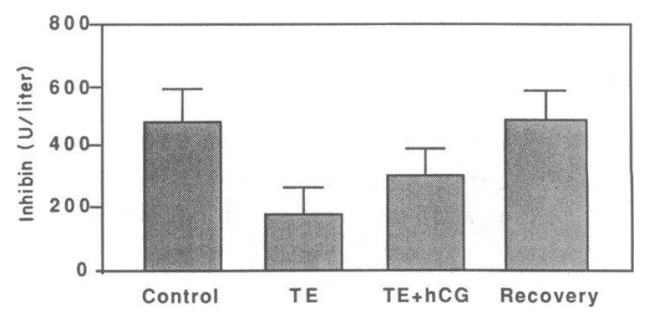

Figure 3. Serum inhibin levels during testosterone (200 mg TE i.m. weekly) alone, T plus hCG (5,000 IU i.m. three times weekly) and recovery periods in three normal men. Values represent mean $\pm S E$ inhibin levels. 
Selective human FSH replacement stimulated inhibin secretion in these gonadotropin-suppressed normal men. The highly purified hFSH preparation used had minimal LH contamination as confirmed by the suppressed levels of serum LH bioactivity throughout treatment. Inhibin levels were not returned to control values despite serum FSH levels two- to threefold higher than the subjects' control values, suggesting that FSH alone is incapable of restoring inhibin secretion to normal. This trophic action of FSH on human inhibin secretion is in keeping with extensive animal studies. FSH replacement stimulated testicular inhibin content and production in hypophysectomized rats (30). Sertoli cells in culture secrete inhibin bioactivity (5-7) and inhibin-like immunoactivity (8, 9) in response to FSH. Similarly, ovarian inhibin production in vivo is stimulated by FSH-containing agents in rats (32) and humans (18).

In the second study, hLH replacement therapy also partially restored inhibin secretion in these gonadotropin-suppressed normal men. The replacement regimen achieved physiological levels of serum LH bioactivity. The hCG replacement regimen used in the third study has been shown previously to achieve a sixfold elevation in serum LH bioactivity (21). Serum inhibin levels increased somewhat more during hCG treatment than during the $\mathrm{hLH}$ regimen but were still lower than control levels. These data indicate that LH-like bioactivity alone, even at supraphysiological levels, cannot restore inhibin secretion to normal levels.

The stimulatory effect of LH upon inhibin secretion was an unanticipated finding in view of previous animal data. hCG replacement had no effect on testicular inhibin production or content in hypophyectomized rats (30). LH had no effect on the secretion of inhibin bio- $(4)$ or immunoactivity $(8,9)$ by Sertoli cells in culture. The mechanism of the LH effect in this study is unclear. During $\mathrm{T}$ suppression in man, despite elevations in serum $\mathrm{T}$, intratesticular $\mathrm{T}$ levels fall dramatically (33). This results from suppression of $\mathrm{LH}$ levels with the concomitant loss of local $\mathrm{T}$ production by the Leydig cells of the testicular interstitium. LH replacement thus could potentially mediate the rise in inhibin secretion by restoring local $\mathrm{T}$ levels. Androgens have been reported to increase Sertoli cell inhibin secretion in vitro (4), although there are several studies to the contrary (6-9). High-dose T treatment in hypophysectomized male rats partially restored inhibin production rates (34) as assessed by the acute accumulation of inhibin in the testis after unilateral efferent duct ligation (35). Finally, other factor(s) produced by the Leydig cell, or other interstitial cells, may subserve the LH effect on inhibin production. For example, androgen-dependent hormonal factors arising from the peritubular cells have been described to affect Sertoli cell production of androgen binding protein (36).

The failure of $\mathrm{LH}, \mathrm{hCG}$, or FSH individually to restore inhibin levels to normal is of interest. It is possible that restoration to normal inhibin secretion requires a synergistic effect of FSH and LH; it is also possible that administration of gonadotropins in a more physiological, pulsatile pattern would have been more effective in stimulating inhibin. The response of serum inhibin shows strikingly similar qualitative changes to those described for the sperm counts in these men. Sperm counts were markedly suppressed during $T$ treatment and were partially restored by replacement of either gonadotropin. Inhibin secretion by the Sertoli cell may be coupled to the spermatogenic process and therefore represent an appropriate feed- back factor upon FSH secretion as generally proposed. Alternatively, inhibin itself may be involved in the process of spermatogenesis as a local growth factor and therefore would be anticipated to rise in parallel with the quantitative outcome of spermatogenesis.

In conclusion, we have shown that in normal men whose gonadotropins were suppressed by testosterone, serum inhibin levels were partially restored by either LH or FSH treatment, demonstrating a role for both gonadotropins in the regulation of inhibin secretion. FSH presumably acts directly upon the Sertoli cell to enhance inhibin secretion, whereas LH may act via an increase in local $\mathrm{T}$ production or by other factor(s).

\section{Acknowledgments}

We thank Ms. Sue Hayward and Dr. David Robertson for their excellent technical assistance in the inhibin RIA, Ms. Liza Noonan for her assistance in the biostatistical analyses, and Maxine M. Pollock for the manuscript preparation.

We appreciate the supply of hormones and reagents from the $\mathrm{Na}-$ tional Hormone and Pituitary Program and the World Health Organization. This study was supported in part by the Australian National Health and Medical Research Council and by National Institutes of Health grant P50-HD-12629 and by the Veterans Administration.

\section{References}

1. Franchimont, P., J. Verstraelen-Proyard, M. T. Hazee-Hagelstein, R. A. Demoulin, J. P. Bourtuignon, and J. Hustin. 1979. Inhibin: from concept to reality. Vitam. Horm. 37:243-302.

2. Steinberger, A., and E. Steinberger. 1976. Secretion of an FSHinhibiting factor by cultured Sertoli cells. Endocrinology. 99:918-921.

3. Eddie, L. W., H. W. G. Baker, A. Dulmanis, R. E. Higginson, and B. Hudson. 1978. Inhibin from cultures of rat seminiferous tubules. J. Endocrinol. 78:217-224.

4. Verhoeven, G., and P. Franchimont. 1983. Regulation of inhibin secretion by Sertoli cell-enriched cultures. Acta Endocrinol. 102:136-143.

5. Le Gac, F., and D. M. de Kretser. 1982. Inhibin production by Sertoli cell cultures. Mol. Cell. Endocrinol. 28:487-498.

6. Ultee-van Gessel, A. M., F. G. Leemborg, F. H. de Jong, and H. J. van der Molen. 1986. In vitro secretion of inhibin-like activity by Sertoli cells from normal and prenatally irradiated immature rats. $J$. Endocrinol. 109:411-418.

7. Ultee-van Gessel, A. M., and F. H. de Jong. 1987. Inhibin-like activity in Sertoli cell culture media and testicular homogenates from rats of various ages. J. Endocrinol. 113:103-110.

8. Bicsak, T. A., W. Vale, J. Vaughan, E. M. Tucker, S. Cappel, and A. J. W. Hsueh. 1987. Hormonal regulation of inhibin production by cultured Sertoli cells. Mol. Cell. Endocrinol. 49:211-217.

9. Ying, S., J. Czvik, A. Becker, N. Ling, N. Ueno, and R. Guillemin. 1987. Secretion of follicle-stimulating hormone and production of inhibin are reciprocally related. Proc. Natl. Acad. Sci. USA. 84:4631-4635.

10. Robertson, D. M., L. M. Foulds, L. Leversha, F. J. Morgan, M. T. W. Hearn, H. G. Burger, R. E. H. Wettenhall, and D. M. de Kretser. 1985. Isolation of inhibin from bovine follicular fluid. Biochem. Biophys. Res. Commun. 126:220-226.

11. Miyamoto, K., Y. Hasegawa, M. Fukuda, M. Nomura, M. Igarashi, K. Kaneawa, and H. Matsuo. 1985. Isolation of porcine follicular fluid inhibin of $32 \mathrm{~K}$ daltons. Biochem. Biophys. Res. Commun. 129:396-403.

12. Leversha, L. J., D. M. Robertson, F. L. de Vos, F. J. Morgan, F. T. W. Hearn, R. E. H. Wettenhall, J. K. Findlay, H. G. Burger, and D. M. de Kretser. 1987. Isolation of inhibin of ovine follicular fluid. $J$. Endocrinol. 113:213-220. 
13. Mason, A. J., J. S. Hayflick, N. Ling, F. Esch, N. Ueno, S.-Y. Ying, R. Guillemin, H. Niall, and P. H. Seeburg. 1985. Complementary DNA sequences of porcine follicular fluid inhibin show precursor structure and homology with transforming growth factor- $\beta$. Nature (Lond.). 318:659-663.

14. Forage, R. G., J. M. Ring, R. W. Brown, B. V. McInerney, G. S. Cobon, R. P. Gregson, D. M. Robertson, F. J. Morgan, M. T. W. Hearn, J. K. Findlay, R. E. H. Wettenhall, H. G. Burger, and D. M. de Kretser. 1986. Cloning and sequence analysis of cDNA species coding for the two subunits of inhibin from bovine follicular fluid. Proc. Natl. Acad. Sci. USA. 83:3091-3095.

15. Mason, A. J., H. D. Niall, and P. H. Seeburg. 1986. Structure of two human ovarian inhibins. Biochem. Biophys. Res. Commun. 135:957-964.

16. McLachlan, R. I., D. M. Robertson, H. G. Burger, and D. M. de Kretser. 1986. The radioimmunoassay of bovine and human follicular fluid and serum inhibin. Mol. Cell. Endocrinol. 46:175-185.

17. McLachlan, R. I., D. M. Robertson, D. L. Healy, H. G. Burger, and D. M. de Kretser. 1987. Circulating immunoreactive inhibin levels during the normal human menstrual cycle. J. Clin. Endocrinol. \& Metab. 65:954-961.

18. McLachlan, R. I., D. M. Robertson, D. L. Healy, D. M. de Kretser, and H. G. Burger. 1986. Plasma inhibin levels during gonadotropin-induced ovarian hyperstimulation for IVF: a new index of follicular function? Lancet. i:1233-1234.

19. McLachlan, R. I., D. L. Healy, D. M. Robertson, H. G. Burger, and D. M. de Kretser. 1987. Circulating immunoactive inhibin in the luteal phase and early gestation of women undergoing ovulation induction. Fertil. Steril. 48:1101-1105.

20. McLachlan, R. I., D. L. Healy, P. J. Lutjen, J. K. Findlay, D. M. de Kretser, and H. G. Burger. 1987. The maternal ovary is not the source of circulating inhibin levels during human pregnancy. Clin. Endocrinol. 27:663-668.

21. Bremner, W. J., A. M. Matsumoto, A. M. Susman, and C. A. Paulsen. 1981. Follicle-stimulating hormone and human spermatogenesis. J. Clin. Invest. 68:1044-1052.

22. Matsumoto, A. M., A. E. Karpas, C. A. Paulsen, and W. J. Bremner. 1983. Reinitiation of sperm production in gonadotropinsuppressed normal men by administration of follicle-stimulating hormone. J. Clin. Invest. 72:1005-1015.

23. Matsumoto, A. M., C. A. Paulsen, and W. J. Bremner. 1984. Stimulation of sperm production by human luteinizing hormone in gonadotropin-suppressed normal men. J. Clin. Endocrinol. \& Metab. 55:882-887.

24. Matsumoto, A. M., and W. J. Bremner. 1985. Stimulation of sperm production by human chorionic gonadotropin after prolonged gonadotropin suppression in normal men. J. Androl. 6:1137-1143.

25. Matsumoto, A. M., A. E. Karpas, and W. J. Bremner. 1986. Chronic human chorionic gonadotropin administration in normal men: evidence that follicle-stimulating hormone is necessary for the maintenance of quantitatively normal spermatogenesis in man. $J$. Clin. Endocrinol. \& Metab. 62:1184-1192.

26. Scott, R. S., H. G. Burger, and H. Quigg. 1980. A simple and rapid in vitro bioassay for inhibin. Endocrinology. 107:1536-1542.

27. Reiter, E. O., H. E. Kulin, and S. M. Hamwood. 1973. Preparation of urine containing small amounts of FSH and LH for radioimmunoassay: comparison of the kaolin-acetone in acetone extraction techniques. J. Clin. Endocrinol. \& Metab. 36:661-665.

28. Van Damme, M. P., D. M. Robertson, and E. Diczfalusy. 1974. An improved in vitro bioassay method for measuring luteinizing hormone (LH) activity using mouse Leydig cell preparations. Acta. Endocrinol. 77:655-671.

29. Dufau, M. L., G. D. Hodgen, A. L. Goodman, and K. J. Catt. 1977. Bioassays of circulating luteinizing hormone in the rhesus monkey: comparison with radioimmunoassay during physiological changes. Endocrinology. 100:1557-1565.

30. Au, C. L., D. M. Robertson, and D. M. de Kretser. 1985. Effects of hypophysectomy and subsequent FSH in testosterone treatment on inhibin production by adult rat testis. Endocrinology. 105:1-6.

31. McLachlan, R. I., D. M. Robertson, and H. G. Burger. 1987. Inhibin: a non-steroidal regulator of pituitary follicle-stimulating hormone. In Clinical Endocrinology and Metabolism: Reproductive Endocrinology. H. G. Burger, editor. Ballière Tindall, London. 89-112.

32. Lee, V. K. W., J. McMaster, H. Quigg, J. K. Findlay, and L. J. Leversha. 1981. Ovarian and peripheral blood inhibin concentrations increase with gonadotropin treatment in immature rats. Endocrinology. 108:2403-2405.

33. Morse, H. C., N. Horike, M. J. Rowley, and C. Heller. 1973. Testosterone concentrations in testes of normal men: effects of testosterone proprionate administration. J. Clin. Endocrinol. \& Metab. 37:882-886.

34. Au, C. L., D. C. Irby, D. M. Robertson, and D. M. de Kretser. 1986. Effects of testosterone on testicular inhibin and fluid production in intact and hypophysectomized adult rats. J. Reprod. Fertil. 76:257266.

35. Au, C. L., D. M. Robertson, and D. M. de Kretser. 1984. An in-vivo method for estimating inhibin production by adult rat testes. $J$. Reprod. Fertil. 71:259-265.

36. Skinner, M. K., and I. B. Fritz. 1985. Androgen stimulation of Sertoli cell function is enhanced by peritubular cells. Mol. Cell. Endocrinol. 40:115-122. 